\title{
Деятельностно-технологический критерий готовности будущих логопедов к профессиональной деятельности
}

\author{
С. В. Цымбал-Слатвинская \\ Уманский государственный педагогический университет имени Павла Тычины, г. Умань, Украина \\ Corresponding author. E-mail: lanatsimbal@gmail.com
}

Paper received 24.08.19; Accepted for publication 08.09.19.

https://doi.org/10.31174/SEND-PP2019-202VII82-13

Аннотация. В статье проанализирована структура готовности логопедов к профессиональной деятельности. Определена значимость в их подготовке деятельно-технологического критерия. Деятельностный компонент включает создание и использование средств, обеспечивающих практическое овладение знаниями, умениями. За обобщенным анализом определено, что для профессиональной деятельности логопеда необходимы следующие умения: гностические, методические, организационные, коммуникативные, прогностические, производственно-операционные, специальные. Профессиональную компетенцию логопеда рассмотрено с позиции основных операционных функций и оценено через уровень сформированности профессионально-педагогических умений.

Ключевые слова: логопед, нарушение речи, педагогический опыт, профессиональная подготовка, профессиональная деятельность, профессиональная компетентность.

Введение. Готовность будущих логопедов к профессиональной деятельности имеет свою структуру. Одним из элементов этой структуры определены деятельно-технологический критерий готовности, включающий профессионально значимые умения. Обучение не может быть успешным, если оно не развивает определенную систему умений. Умения по своей природе многозначные: умения простые, умения специальные, умения, связанные с организационными действиями, с интеллектуальными действиями и т. д.

Умение применять знания в практической работе вообще зависит от того, каким путем студент пришел к запоминанию. Если они заучены без осмысления, анализа фактов, явлений, студент не умеет их применять. Для того, чтобы знания были прочными, необходимо их осмысление студентом [1, с. 59].

Знания и умения, непосредственно и органично связаны друг с другом, взаимообусловлены, входят в структуру всех свойств личности.

Краткий обзор публикаций по теме. Проблемы подготовки будущих логопедов к профессиональной деятельности рассматривали ряд авторов, среди которых Акименко В. М. [1], Бойко Т. Н. [2], Болтакова Н. И. [3], Жаркова Ю. В. [4], Жукатинская Е. Н. [5], Стахова Л. Л. [6] и другие. Анализ их исследований позволил сделать вывод, что, как и любая другая, профессиональная деятельность логопеда определяется целым рядом характеристик.

Деятельностный компонент, по определению $\mathrm{H}$. Болтаковой, включает создание и использование средств, обеспечивающих практическое овладение знаниями и умениями, позволяющими решать профессионально-педагогические задачи в различных ситуациях общения [3, с. 68].

Ю. Жаркова рассматривает важность для подготовки будущего логопеда таких умений: проектировочные умения, наличие которых является необходимым условием успешного осуществления любого вида деятельности; организаторские умения как совокупность практических приемов и способов организации деятельности; исполнительские умения, направленные на реализацию запланированной работы в рамках осуществления деятельности; оценочные умения, пред- полагающие оценку соответствия полученных результатов заданным целям и задачам [4, с. 3$]$.

Профессиональная компетентность с позиции основных операционных функций учителя-логопеда Л. Стахов оценивает через уровень сформированности профессионально-педагогических умений, таких как: прогностические умения (постановка целей и задач; отбор способов достижения целей, задач; предсказание результата; предсказание возможных отклонений и нежелательных явлений; определение этапов деятельности; приблизительная оценка предполагаемых затрат средств, труда и времени участников деятельности, планирование содержания взаимодействия участников деятельности); проектные умения (перевод цели и содержания проектной деятельности в конкретные задачи, обоснование способов их поэтапной реализации, планирование содержания и видов деятельности участников проектной деятельности с учетом их потребностей и интересов, возможностей материальной базы, собственного опыта и личностноделовых качеств, определение комплекса целей и задач для каждого этапа проектной деятельности); рефлексивные умения (определение правильности постановки целей, их трансформации в конкретные задачи, оценка адекватности комплекса определенных задач имеющимся условиям, анализ соответствия содержания деятельности поставленной задачей, оценка эффективности применяемых методов, приемов и средств деятельности, определение причин успехов и неудач, ошибок и трудностей в процессе реализации поставленных задач деятельности) [6, с. 47].

Цель. Статья направлена на проведение анализа структуры готовности логопедов к профессиональной деятельности и обоснование значения в их подготовке деятельно-технологического критерия.

Материалы и методы. Для решения поставленных задач применен комплекс взаимосвязанных методов исследования: общенаучных - анализ, синтез, индукция, дедукция, абстрагирование, сравнение, обобщение, систематизация, классификация (для обоснования исходных теоретических позиций, систематизации взглядов и подходов с определенной проблематики) эмпирических -изучение стратегий, националь- 
ных докладов и других документов о состоянии специального образования (для отслеживания объективных и субъективных мнений специалистов относительно выделения приоритетных направлений развития специального, в частности логопедического образования); динамическое наблюдение в процессе логопедической работы; педагогический эксперимент: пилотажный - для получении информации о работе логопедов, ориентированных на работу с детьми с нарушением речи, констатирующий - для определения исходного состояния готовности будущих логопедов в условиях информационно-образовательной среды высших учебных заведений; статистических методы обработки экспериментальных данных: количественный и качественный анализ, математическая обработка экспериментального материала.

Опытно-экспериментальная работа осуществлялась на базе Уманского государственного педагогического университета имени Павла Тычины, Центральноукраинского государственного педагогического университета имени Владимира Винниченко, Ровенского государственного гуманитарного университета. На разных этапах в исследовании принимали участие 482 студента, из них 405 в контрольных и экспериментальных группах и 23 преподавателя высших учебных заведений.

Результаты и их обсуждение. За общим анализом умений, предложенных учеными, считаем, что для готовности будущих логопедов к профессиональной деятельности по деятельностно-технологическому критерию необходимы следующие умения:

гностические - умение получения общих и психолого-педагогических знаний; предусмотрено осуществление поиска необходимой информации, получения новой информации, ее адекватной оценки, аналитической и синтетической обработки педагогической информации;

методические - общепедагогические умения, определение конкретных целей коррекционного процесса, выбора адекватных форм, методов и средств обучения, применение их в процессе педагогического воздействия;

организационные - умение организации и реализации коррекционно-развивающего процесса, организации профессиональной деятельности, организации самообразования, планирование коррекционноразвивающих мероприятий, рационального распределения и использования времени;

коммуникативные - общепедагогические умения, включающие создание положительного психологического климата на уроке и вне его;

прогностические - общепедагогические умения, прогнозирование успешности учебно-развивающего процесса, проведение диагностики речевого развития ребенка, осуществление контроля за коррекционным процессом и результатом;

рефлексивные умения - способность к самоанализу и самооценке профессиональной деятельности;

производственно-операционные умения - умения по смежным профессиям (например, воспитателя, методиста);

специальные умения - узкопрофессиональные умения в рамках коррекционной педагогики (прове- дение гимнастики, массажа органов артикуляционного аппарата, упражнений для развития речевого дыхания, фонематического слуха, владение способами постановки звуков, коррекции речевых нарушений различной степени сложности).

В процессе производственной практики в будущих логопедов должны быть сформированными такие группы умений:

1) умение увидеть в педагогической ситуации проблему и оформить ее в виде соответствующих задач; умение при постановке педагогической задачи ориентироваться на ребенка с нарушением речи как на активного соучастника учебно-воспитательного процесса, имеющего собственные мотивы и цели; умение изучать и преобразовывать педагогическую ситуацию; умение конкретизировать педагогические задачи в поэтапные и оперативные, принимать оптимальное педагогическое решение в условиях неопределенности, гибко перестраивать педагогические цели и задачи по мере изменения педагогической ситуации; умение с достоинством выходить из трудных педагогических ситуаций; умение предвидеть близкие и отдаленные результаты решения педагогических задач;

2) педагогические умения, которые объединяют три подгруппы:

а) подгруппа «чему учить»: умение работать с содержанием учебного материала (осведомленность в новых концепциях и технологиях обучения, умение выделять ключевые идеи учебного задания, использовать понятия, термины, дискуссии в соответствующей отрасли науки); способность к педагогической интерпретации информации, поступающей из газет, журналов; формирование у детей с нарушением речи специальных умений и навыков и т.д.;

б) подгруппа «кого учить»: умение изучать у детей с нарушением речи состояние отдельных психических функций (памяти, мышления, внимания, речи и т.п.) и целостных характеристик видов деятельности (учебной, трудовой), обученности и воспитанности учащихся, различать успеваемость и личностные качества детей с нарушением речи, умение выявлять не только имеющийся уровень, но и зону ближайшего развития детей с нарушением речи, условия их перехода с одного уровня развития на другой, предвидеть возможные и учитывать типичные трудности детей с нарушением речи; умение выходить из мотивации самих детей в планировании и организации учебновоспитательного процесса; умение проектировать и формировать у детей с нарушением речи отсутствующие в них уровни деятельности;

в) подгруппа «как учить»: умение отбирать и применять сочетания приемов и форм обучения и воспитания, учитывать расход сил и времени детей с нарушением речи и воспитателя, логопеда; умение сравнивать и обобщать педагогические ситуации, переносить педагогические приемы в другие ситуации и комбинировать их, применять дифференцированный и индивидуальный подход к детям с нарушением речи, организовывать их самостоятельную учебную деятельность; умение находить несколько способов решения педагогической задачи, владеть вариативным педагогическим решением;

3) умение использовать психолого-педагогические 
знания и осведомленность в современном состоянии психологии и педагогики, передового педагогического опыта; умение фиксировать, регистрировать процесс и результаты своего труда; умение соотносить проблемы детей с нарушением речи с недостатками в своей работе; умение видеть сильные и слабые стороны своего труда, оценить свой индивидуальный стиль; анализировать и обобщать свой опыт, соотносить его с опытом других логопедов; умение строить планы развития своей педагогической деятельности.

Оценка сформированности деятельностнотехнологического критерия готовности осуществлялась также по входящему в него рефлексивному компоненту. Рефлексивные умения включают: мгновенную оценку ситуации занятия, определение, оценка методов контроля за усвоением изучаемого материала; моделирование внутреннего мира ребенка с нарушением речи в контексте его отношения к воспитателям и другим детям; анализ, оценку и корректировку намеченных ранее планов и мероприятий в ситуации изменения условий педагогического процесса; обобщение факторов и явлений занятий относительно выявленного отношения детей с нарушением речи к учебному материалу; методическую оценку учебного материала в выявлении возможностей детей при его усвоении; анализ и оценку используемых проблемных ситуаций на занятиях как отношения (положительного или отрицательного) детей к ним; анализ и оценку своего педагогического опыта в учебной деятельности, соотношение с новыми психологопедагогическими условиями и учебными ситуациями на занятиях; анализ положительных и отрицательных результатов собственной педагогической деятельности в соотношении результатов с конкретными условиями; выявление причин успехов и неудач, ошибок и трудностей в ходе реализации намеченных задач обучения и воспитания; соотнесение своего опыта педагогической деятельности с нормативами, рекомендациями, выработанными в педагогической науке.

Анализ этой классификации позволяет констатировать, что рефлексивные умения проходят через все группы общих умений педагога, и рефлексивная компетентность является системообразующим компонентом профессиональной компетентности будущего логопеда.

Профессионально-деятельностные умения, по исследованиям Т. Бойко, образуют комплекс и позволяют будущем логопеду:

- уметь: обосновывать социальную значимость своей профессии; анализировать социально значимые проблемы и процессы; проектировать, конструировать и регулировать взаимодействие специалистов в решении социальных профессиональных задач; организовывать совместную деятельность и межличностное взаимодействие субъектов информационнообразовательной среды; выполнять профессиональные задачи, соблюдая принципы профессиональной этики; осуществлять самодиагностику, самообразование и самовоспитание;

- владеть: методикой и технологией решения социально-педагогических задач, методикой взаимодействия специалистов в организациях различной направленности; умением планировать свою работу и ставить социально ориентированные задачи; анализировать результаты социально-педагогической деятельности;

- приобретать опыт деятельности: в совместном с другими специалистами решении социальных профессиональных задач; в изучении различных методов, методик и приемов социально-педагогической деятельности, находить адекватные способы поведения в различных непредвиденных ситуациях [2, с. 39].

Анализ профессиональных умений связан с опытом жизнедеятельности студентов, наличием в их поведении определенной совокупности профессионально значимых социально-бытовых умений, уровнем профессиональных региональных стандартов.

Каждое общепрофессиональное умение специалиста может рассматриваться как определенная совокупность интеллектуальных и практических действий, целенаправленных и взаимосвязанных, выполняемых в определенной последовательности. Сознательное педагогическое действие - это проектируемое, прогнозируемое действие, основанное на осмыслении его цели, способов выполнения, принципов выбора этих способов [5, с. 78].

Итак, знания, умения, приобретенные в результате общения и опыта профессиональной деятельности, являются необходимыми условиями формирования готовности будущих логопедов к профессиональной деятельности. Указанные характеристики профессиональной компетентности и профессиональных умений педагога нельзя рассматривать изолированно, поскольку они имеют интегративный, целостный характер, являются продуктом профессиональной подготовки в целом.

В структуру готовности будущих логопедов входят такие действия: определение проблем, формулирование целей, задач, выбор форм работы и выполнения системы функций (информационного обеспечения учебно-воспитательного процесса, выработки, принятия управленческих действий и действий воспитанников, создание информационно-образовательной среды). Считаем эти действия существенными, поскольку они учат логопедов не только воспитывать детей с нарушением речи, но и реализовывать важные дидактические, воспитательные и оздоровительные проблемы, цели, задачи с момента их обнаружения до получения детьми с нарушением речи положительного результата.

В системе профессиональной подготовки будущих логопедов акцент делается на получении субъектного опыта на основе их раннего приобщения к профессиональной деятельности; логика образовательного процесса строится по схеме: от практики, субъектного опыта - к теоретическим обобщениям. Однако эта связь неоднозначна: не всегда компетентность тем выше, чем больше опыт работы логопеда.

По уровню творческой самостоятельности Л. Стахова выделяет следующие типы педагогического опыта: репродуктивный (деятельность педагога не несет в себе чего-то принципиально нового, направленная на четкое выполнение профессиональных обязанностей с неотъемлемым элементом новизны) инновационный (деятельность педагога связана с творческим, оригинальным, присущим только этому педа- 
гогу использованием известных форм и методов с внесением элементов новизны) новаторский (деятельность педагога направлена на существенные изменения в учебно-воспитательном процессе) [6, с. 51].

Образно говоря, компетентным нельзя стать, если повторять имеющийся опыт, не продумывать альтернативные варианты решений, не отбирать из них оптимальные.

Выводы. Показателями деятельностно-технологического критерия выбрано умения, навыки, операции и действия, опыт, сознательный контроль результатов своей деятельности по следующим признакам: степень овладения профессиональными умениями и навыками; способность работать по различным технологиям и методическим системам; владение информационными технологиями, интенсивность использования информационных технологий информационно-образовательной среды, умение теоретически обосновано выбирать методы, средства, организационные формы, приемы обучения и воспитания детей с нарушением речи в соответствии со знаниями особенностей их развития, овладение умениями по развитию речевой деятельности детей с речевыми нарушениями; применение на практике новых методик осуществления дифференцированного и индивидуального подходов к ученикам, которые имеют речевые нарушения; умение предвидеть характер ответных реакций младших школьников на запланированную систему коррекционных воздействий, уметь организовывать совместную деятельность и межличностное взаимодействие субъектов образовательной среды; обретение опыта деятельности по изучению различных методов, методик и приемов социально направленной коррекционной деятельности, умение осуществлять педагогический самоанализ.

\section{ЛИТЕРАТУРА}

1. Акименко В. М. Подготовка студентов-логопедов к коррекции звукопроизношения средствами моделирования: дис. .... канд. пед. наук. Ставрополь, 2003. 187 с.

2. Бойко Т. Н. Формирование социально-педагогической компетентности будущих учителей-логопедов в процессе педагогической практики: дис. ... канд. пед. наук. Брянск, 2016. $211 \mathrm{c}$

3. Болтакова Н. И. Формирование коммуникативной компетентности будущих логопедов как необходимое условие подготовки к речевому развитию детей. Проблеми сучасної психології. 2013. Вип. 20. С. 60-68.

4. Жаркова Ю. В. Методика исследования готовности будущего учителя-логопеда к проектной деятельности. Ога-

pёв-online. Электронное периодическое издание для студентов и аспирантов. 2017. № 9. URL: http://journal.mrsu.ru/arts/metodika-issledovaniyagotovnosti-budushhego-uchitelya-logopeda-k-proektnojdeyatelnosti (дата обращения: 04.04.2019).

5. Жукатинская Е. Н. Формирование профессиональной компетентности будущего учителя-логопеда: дис. ... канд. пед. наук. Липецк, 2008. 226 с.

6. Стахова Л. Л. Проектирование методической системы развития профессиональной компетентности учителялогопеда дошкольного образовательного учреждения в условиях профессиональной среды: дис. ... канд. пед. наук. Тамбов, 2010. 195 с.

\section{REFERENCES}

1. Akimenko, V. M. Training the students - speech therapists to correct sound pronunciation by modelling tools. Ph.D. dissertation. Stavropol, Russia. 2003.

2. Bojko, T. N. Forming socio-pedagogical competence of the future teachers - speech therapists in the process of teaching practice. Ph.D. dissertation. Bryansk, Russia. 2016.

3. Boltakova, N. I. Forming communicative competence of the future speech therapists as a necessary condition for preparing for children's speech development. Problems of modern psychology, 2013. Is. 20. P. 60-68.

4. Zharkova, Ju. V. The technique of studying the readiness of the future teacher - speech therapist to project activities. Og-
arjov-online,
2017.
No. 9.
URL: http://journal.mrsu.ru/arts/metodika-issledovaniya- gotovnosti-budushhego-uchitelya-logopeda-k-proektnoj- deyatelnosti (Retrieved: 04.04.2019).
5. Zhukatinskaja E. N. Forming professional competence of the future teacher-speech therapist. Ph.D. dissertation. Lipetsk, Russia. 2008.
6. Stahova, L. L. Constructing a methodological system of the development of professional competence of the speech thera- pist of a preschool educational institution in a professional environment. Ph.D. dissertation. Tambov, Russia. 2010.

\section{Activity-technological criterion of future speech therapists' readiness for professional activity \\ S. Tsymbal-Slatvinska}

Abstract. The purpose of the paper is to analyse the structure of speech therapist readiness for professional activity. The author has determined the importance of activity-technological criterion in the training of speech therapists. The activity component involves the creation of conditions and the use of means that ensure the practical mastery of knowledge and skills. According to the general analysis it has been revealed that gnostic, methodical, organizational, communicative, prognostic, production-operational, special skills are required for the professional activity of speech therapists. Professional competence of speech therapist has been considered through the basic operational functions and evaluated due to the level of formation of professional and pedagogical skills.

Keywords: speech therapists, speech disorders, teaching experience, training, professional activity, professional competence. 